\title{
Changes in Income Distribution for Different Family Types in Poland
}

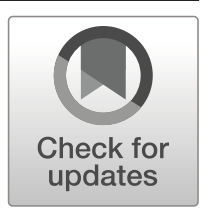

\author{
Alina Jędrzejczak ${ }^{1}$ (D) Dorota Pekasiewicz $^{1}$ (D)
}

Published online: 17 June 2020

(C) The Author(s) 2020

\begin{abstract}
This paper compares income distributions for the family types distinguished by the number of children. The primary contribution to the literature of the current paper was to provide evidence that between 2015 and 2016, when the child benefit Family $500+$ program was implemented, there was a reduction in income inequality and poverty, especially for families with many children. The basis for the calculations was microdata from the Household Budget Survey conducted by Statistics Poland. It is the basic source of information on the revenues, expenditures, quantitative food consumption and other aspects of the living conditions of particular groups of the population. The data obtained from this survey allow for the analysis of different factors influencing income distribution and its inequality by means of selected income inequality measures: Gini index and the quintile and decile share ratios. To conduct poverty analysis, the head-count ratio, poverty gap and squared poverty gap indices were applied. The results of the analysis revealed noticeable changes in the income distribution of Polish households, which resulted in poverty reduction, especially for families with many children. In total, mean equivalent income increased by 127 PLN and poverty decreased by 1.2 percentage points. Approximately 160,000 households came out of poverty. The twosample parametric tests for differences in means and proportions showed that in 2016, the means were significantly larger and poverty rates significantly smaller for all family types but the differences were larger for large families.
\end{abstract}

Keywords Income distribution $\cdot$ Inequality $\cdot$ Child poverty $\cdot$ Household budgets

JEL Categories $\mathrm{C} 10 \cdot \mathrm{I} 30$

Dorota Pekasiewicz

dorota.pekasiewicz@uni.lodz.pl

1 Department of Statistical Methods, University of Lodz, POW Street No 3/5, 90-255, Lodz, Poland 


\section{Introduction}

The last financial and economic crisis had a serious impact on children and families, with an increase in the proportion of those living in poverty in a number of countries. Thanks to the economic recovery, child poverty in Europe declined, but is still unacceptably high. According to Eurostat (2017) in 2016, 24.8 million children in the European Union, or $26.4 \%$ of the population aged 0 to 17 , were at risk of poverty or social exclusion. This means that the children were living in households with at least one of the following three conditions: at-risk-of-poverty after social transfers (income poverty), severely materially deprived or with very low work intensity. Almost half of the children were at risk of poverty or social exclusion in Romania $(49.2 \%)$ and Bulgaria (45.6\%). They were followed by Greece (37.5\%), Hungary (33.8\%), Spain $(31,7 \%)$, Italy (32.8\%) and Lithuania (32.4\%). At the opposite end of the scale, the lowest percentages of children at risk of poverty or social exclusion were recorded in Denmark (13.8\%), Finland (14.7\%) and Slovenia (14.9\%), ahead of the Czech Republic (17.8\%) and the Netherlands (17.6\%). Poverty deprives children of educational opportunities, childcare, access to health care, adequate food and housing, family support and even protection from violence.

In the framework of the Europe 2020 Strategy, in 20 February 2013, the European Commission published a European recommendation on child poverty. According to this act (European Commission 2013, p. 1): "children are more at risk of poverty or social exclusion than the overall population in a large majority of EU countries; children growing up in poverty or social exclusion are less likely than their better-off peers to do well in school, enjoy good health and realise their full potential later in life". Moreover "early intervention and prevention are essential for developing more effective and efficient policies, as public expenditure addressing the consequences of child poverty and social exclusion tends to be greater than that needed for intervening at an early age". The recommendation, which is a key issue within the Europe 2020 Strategy, is expected to give children visibility in the context of the smart, sustainable, and inclusive growth that the EU envisages. The recommendation could serve as a resource to help member states achieve the targets of lifting 20 million people out of poverty and social exclusion and reducing the rate of leaving school early to below $10 \%$ by 2020 .

Strategies that can be launched comprise adequate income support (fiscal incentives, family and child benefits, housing benefits and minimum income schemes). These strategies should be combined with support to parents to access the labour market and services that are essential to children's outcomes, such as quality (pre-school) education, health, housing and social services. Also important are opportunities to participate and use their rights, which help children live up to their full potential and contribute to their resilience.

According to the Eurostat database (Eurostat 2017), the child poverty rate (children at risk of poverty and social exclusion) for Poland in 2016 was 23.3\%. In the next year (2017) the rate decreased to $16.8 \%$, placing Poland close to Germany (18\%). Reasons for this change may include the reduced unemployment rate associated with the notable economic growth observed during the last few years as well as the pro-family policy of the government. 
The aim of this paper was to compare income inequality and poverty for different types of Polish households defined by the number of children. Special attention was paid to changes in income distribution during the period 2015-2016, when the Family $500+$ child benefit program, aimed at supporting Polish families with children, was launched. Under the program, parents can receive a tax-free benefit of PLN 500 (about EUR 120) per month for the second and any consecutive children until they reach age 18. A microsimulation analysis (Szarfenberg 2017) revealed that the impact of the program on the structure of poverty risk in Poland can be substantial. The influence of the number of children on the distribution of household incomes, including inequality and poverty, was examined by Jędrzejczak and Kubacki (2013), among others. The relationship between the structure of the household and income inequality and poverty with particular emphasis on vulnerable groups, including families with children, has also been studied for many countries (e.g. Jäntti and Bradbury 2001) and for the European Union (Eurostat 2013). These studies suggest that household composition has a significant impact on income and poverty diversity in many countries, especially in southern and eastern Europe, where couples with dependent children are at more than an average at risk of poverty. Jäntti and Bradbury (2001) compared programs aimed at counteracting poverty among children, including family support benefits and tax relief schemes. They revealed that comprehensive family-policy packages including a general child allowance, like Family 500+, aimed at supporting families with children can be more effective than tax-relief schemes. The long-run impact of family support has also been examined recently (Butcher 2017; Aizer et al. 2016). Monti et al. (2015) conducted an interesting analysis of the impact of the Italian income tax system on the income of households with children.

The current research was based on individual data from the Household Budget Survey conducted by the Polish central statistical bureau (Statistics Poland 2015, 2016). This survey is the basic source of information on revenues, expenditures, food consumption and other aspects of the living conditions of subgroups of the population.

The following family types were considered: marriages without children, marriages with one child, marriages with two children, marriages with three children, marriages with four and more children. Statistics Poland $(2015,2016)$ does not classify persons living in informal relationships as a specific category and includes them in existing household types. Single parent households (less than $2 \%$ of the sample) were excluded due to lack of data on number of children. To account for the influence of different household sizes on the results of the inequality and poverty analysis, for each household, available income was converted into equivalent income. Equivalence scales enable comparisons of the material situation of households differing in size and demographic structure. The new Organisation for Economic Cooperation and Development (OECD) square root scale was used, dividing household income by the square root of household size (Organisation for Economic Cooperation and Development 2019).

The data obtained from the Household Budget Survey permit analysis of different factors influencing income distribution and inequality. For the inequality analysis, besides the popular Gini index, known to be proportionally oversensitive to changes in the middle-income distribution, the quintile and decile share ratios were used. They are more sensitive to changes in the tails of the income distributions. To conduct poverty analysis, head-count-ratio as well as the poverty gap and squared poverty gap 
indices were estimated, which permitted measurement of the intensity, depth, and severity of poverty for different family types.

\section{Research Methodology}

Income inequality refers to the degree of income difference among various individuals or segments of a population. Inequality indices play an important role in income distribution analysis for comparisons across different geographical regions, social groups or family types, and time periods. It is well known that high income inequality can have several undesirable political and social consequences, such as poverty and the polarization of economic groups, which is the process of further differentiation of the poor and the rich, while reducing the middle-income group. Inequality and poverty may not always be positively correlated although they are usually seen as similar and are in fact highly related concepts. One can imagine a strictly egalitarian distribution of incomes, where all the income receivers are poor, or a highly dispersed population not affected by poverty. However, most empirical evidence based on income data from many countries found a strong positive correlation between inequality and poverty. High income inequality is considered the basic determinant of poverty (Hills et al. 2019).

The Gini index (Greselin et al. 2013), is the most widely used measure of income inequality, mainly because of its clear economic interpretation. Over its 100-year history, numerous formulas and definitions have been developed. In representative studies, the version of the Gini coefficient estimator often used is the one in which the values of the random variable $Y$ are replaced with expanded values accounting for the sampling scheme (Jędrzejczak 2012):

$$
\widehat{G}=\frac{2 \sum_{i=1}^{n}\left(w_{i} y_{(i)} \sum_{j=1}^{i} w_{j}\right)-\sum_{i=1}^{n} w_{i} y_{(i)}}{\left(\sum_{i=1}^{n} w_{i}\right) \sum_{i=1}^{n} w_{i} y_{(i)}}-1,
$$

where $y_{(i)}$ is household incomes in a non-descending order, $w_{j}$ is the survey weight for the $i$-th economic unit and the $\sum_{j=1}^{i} w_{j}$ stands for the rank of the $i$-th economic unit in the $n$ element sample.

Distribution quantiles of a random variable $Y$, identified as household or personal income, or the estimators of these quantiles, have been applied to the construction of the inequality indices as the quintile dispersion ratio and decile dispersion ratio (Foster et al. 1984). The quintile share ratio can also be defined as the ratio of the sum of incomes of the richest $20 \%$ of the population to the sum of incomes of the poorest $20 \%$ :

$$
\widehat{W}_{20: 20}=\frac{\sum_{i \in G K_{5}} w_{i} y_{i}}{\sum_{i \in G K_{1}} w_{i} y_{i}},
$$


where $G K_{j}$ is the $j$ th quintile group. Similar ratios can also be calculated for other quantiles, such as deciles or percentiles (95th and 5th) of income distributions. The decile share ratio has the following form:

$$
\widehat{W}_{10: 10}=\frac{\sum_{i \in G D_{10}} w_{i} y_{i}}{\sum_{i \in G D_{1}} w_{i} y_{i}},
$$

where $G D_{j}$ is the $j$ th decile group. The reciprocal of the decile share ratio takes values from the interval $(0,1)$ and is called the disparity index or the dispersion index for the end portions of the distribution:

$$
\widehat{K}_{1 / 10}=\frac{\sum_{i \in G D_{1}} w_{i} y_{i}}{\sum_{i \in G \mathrm{D}_{10}} w_{i} y_{i}} .
$$

If the index $\widehat{K}_{1 / 10}$ is closer to the 1 , the inequality is lower (mean incomes in the extreme decile groups are the same).

During a thorough income distribution analysis, the problem of inequality measurement is usually interrelated with the estimation of poverty and occasionally wealth indices for the population groups. To obtain reliable poverty characteristics, it is crucial to define and estimate the poverty threshold. There are numerous definitions of this threshold, using the absolute or relative approach. The relative poverty line utilized by Eurostat is $y_{p}^{*}=0,6 M e$, where $M e$ is a median of equivalent income distribution. A comprehensive review of absolute and relative approaches to poverty measurement with special attention paid to data quality aspects can be found in Lemmi et al. (2019).

The most popular poverty index is the head-count ratio, also called the at-risk-ofpoverty rate (ARPR):

$$
\widehat{W}_{p}=\frac{n_{p}}{n}
$$

where: $n_{p}$ is the number of poor individuals or households (with income below the poverty line) and $n$ denotes the number of all households. This index determines the share of households whose equivalent income (or consumption) is below a poverty threshold.

The head-count ratio (5) can be estimated from the $n$-element sample data by means of the following formula:

$$
\widehat{W}_{p}=\frac{\sum_{i=1}^{n} I_{i} w_{i}}{\sum_{i=1}^{n} w_{i}}
$$

where: $I_{i}$ is the indicator function taking the value of 1 when the $i$-th household equivalent income is below the poverty line, and taking the value of 0 in the opposite situation, and $w_{i}$ is the survey weight for $i$-th economic unit. 
The poverty gap index provides information regarding the distance of households from the poverty line. This measure captures the mean aggregate income or consumption shortfall relative to the poverty line across the whole population. Estimators of the poverty gap index, which incorporate sampling weights $w_{i}$, have the following form:

$$
\widehat{P G_{p}}=\frac{\sum_{i=1}^{n_{p}}\left(\left(y_{p}^{*}-y_{i}\right) / y_{p}^{*}\right) w_{i}}{\sum_{i=1}^{n_{p}} w_{i}}
$$

where: $y_{i}$ is household equivalent income, $y_{p}^{*}$ denotes the poverty line (poverty threshold), $n_{p}$ is the number of poor households and $w_{i}$ is the survey weight for the $i$ th household.

The squared poverty gap index (poverty severity index), estimated from the following expression,

$$
\widehat{P S}_{p}=\frac{\sum_{i=1}^{n_{p}}\left(\frac{y_{p}^{*}-y_{i}}{y_{p}^{*}}\right)^{2} w_{i}}{\sum_{i=1}^{n_{p}} w_{i}}
$$

takes into account not only the distance separating the poor from the poverty line (poverty gap), but also inequality among the poor. The squared poverty gap index places higher weight on those households further away from the poverty line.

\section{Comparative Analysis of the Basic Statistical Characteristics of the Income Distribution for the Polish Households}

The empirical analysis presented herein is based on the Household Budget Survey (HBS) which is a random sample of the Polish households selected by Statistics Poland in the years 2015 and 2016. The subject of the analysis was household available income. To account for the influence of different household sizes on the results of the inequality and poverty analysis for each household, available income was converted into equivalent income using the OECD scale. To generalise the results, appropriate survey weights were taken into account when estimating statistical characteristics of particular family types.

Table 1 presents basic statistical characteristics of household available income for the whole country and for the distinguished family types in the considered period. This table shows that between the years 2015 and 2016 the average incomes increased for all family types. Moreover, the distributions of income became more homogenous relative to their means; i.e. variability between the mean incomes for different family types, calculated by the coefficient of variation (not displayed in the table) decreased from $15.6 \%$ in 2015 to $7.7 \%$ in 2016 . Despite these important observations, the assessment of income changes based on only the average income and its dispersion seems insufficient as income distributions present high positive asymmetry and heavy tails. Therefore, the article later presents the results of the study of income inequality and poverty. 
Table 1 Statistical characteristics of empirical income distribution by distinguished family type

\begin{tabular}{lccrcccc}
\hline Family type & Year & $\begin{array}{l}\text { No. of } \\
\text { households }\end{array}$ & $\begin{array}{l}\text { Min. } \\
{[\text { PLN] }]}\end{array}$ & $\begin{array}{l}\text { Max. } \\
{[\text { PLN] }}\end{array}$ & $\begin{array}{l}\text { Median } \\
{[\text { PLN] }}\end{array}$ & $\begin{array}{l}\text { Mean } \\
{[\text { PLN] }]}\end{array}$ & $\begin{array}{l}\text { Standard } \\
\text { deviation[PLN] }\end{array}$ \\
\hline Marriages without children & 2015 & 9312 & 6.72 & $105,846.60$ & 2404.16 & 2763.31 & 1858.11 \\
& 2016 & 9405 & 5.21 & $32,390.16$ & 2491.84 & 2842.30 & 1649.48 \\
Marriages with one child & 2015 & 3817 & 21.94 & $20,134.99$ & 2430.65 & 2773.50 & 1686.58 \\
& 2016 & 3701 & 1.27 & $30,105.58$ & 2540.34 & 2891.24 & 1751.83 \\
Marriages with two & 2015 & 3964 & 13.34 & $67,370.00$ & 2172.48 & 2580.15 & 2107.62 \\
children & 2016 & 3523 & 1.48 & $41,160.00$ & 2430.00 & 2784.24 & 1699.57 \\
Marriages with three & 2015 & 993 & 10.54 & $19,829.81$ & 1796.90 & 2133.35 & 1404.66 \\
children & 2016 & 810 & 8.94 & $10,336.05$ & 2213.71 & 2513.95 & 1450.78 \\
Marriages with four and & 2015 & 289 & 14.25 & 7348.47 & 1487.86 & 1719.00 & 1009.98 \\
more children & 2016 & 192 & 163.79 & $10,055.37$ & 2017.97 & 2318.13 & 1342.10 \\
Total & 2015 & 36,860 & 1.77 & $105,846.64$ & 2097.68 & 2425.31 & 1731.37 \\
& 2016 & 36,616 & 1.27 & $333,978.50$ & 2238.56 & 2552.63 & 1572.81 \\
\hline
\end{tabular}

Values are weighted. Source: Own calculations using data from the Household Budget Survey (Statistics Poland 2015, 2016)

\section{Evaluation of Income Inequality and Poverty}

The results of the inequality analysis are in Table 2 . When comparing the family types within the same period, they have relatively similar characteristics which demonstrates a similar degree of inequality, but comparing the values of the indices for the same groups between 2015 and 2016, one can notice a clear decrease in inequality. In 2016, the Gini index as well as the quintile $\left(\widehat{W}_{20 / 20}\right)$ and decile $\left(\widehat{W}_{10 / 10}\right)$ share ratios decreased, while the disparity index $\widehat{K}_{1 / 10}$, which measures dispersion for the end portions of the distribution, increased in relation to 2015. The change in the disparity index reveals a reduction in disproportions between extreme decile groups. The only

Table 2 Estimated inequality measures by family type in the years 2015-2016

\begin{tabular}{|c|c|c|c|c|c|c|c|c|}
\hline \multirow[t]{2}{*}{ Family type } & \multicolumn{2}{|c|}{$\begin{array}{l}\text { Gini index } \\
(\widehat{G})\end{array}$} & \multicolumn{2}{|c|}{$\begin{array}{l}\text { Quintile share ratio } \\
\left(\widehat{W}_{20: 20}\right)\end{array}$} & \multicolumn{2}{|c|}{$\begin{array}{l}\text { Decile share ratio } \\
\left(\widehat{W}_{10: 10}\right)\end{array}$} & \multicolumn{2}{|c|}{$\begin{array}{l}\text { Disparity index } \\
\left(\widehat{K}_{1 / 10}\right)\end{array}$} \\
\hline & 2015 & 2016 & 2015 & 2016 & 2015 & 2016 & 2015 & 2016 \\
\hline Marriages without children & 0.276 & 0.268 & 4.004 & 3.885 & 6.149 & 6.607 & 0.163 & 0.151 \\
\hline Marriages with one child & 0.288 & 0.260 & 4.397 & 4.125 & 6.948 & 6.444 & 0.144 & 0.155 \\
\hline Marriages with two children & 0.312 & 0.259 & 4.830 & 4.085 & 7.879 & 6.332 & 0.127 & 0.158 \\
\hline Marriages with three children & 0.303 & 0.263 & 4.522 & 4.176 & 7.150 & 6.469 & 0.140 & 0.155 \\
\hline Marriages with four and more & 0.288 & 0.273 & 4.106 & 3.968 & 6.560 & 6.116 & 0.152 & 0.166 \\
\hline Total & 0.297 & 0.265 & 4.495 & 4.170 & 7.039 & 6.383 & 0.142 & 0.157 \\
\hline
\end{tabular}

Values are weighted. Source: Own calculations using data from the Household Budget Survey (Statistics Poland 2015, 2016) 
Table 3 Estimated poverty measures by family type in the years 2015-2016

\begin{tabular}{lllllllll}
\hline Family type & \multicolumn{3}{l}{ Head-count ratio $\left(\widehat{W}_{p}\right)$} & & \multicolumn{2}{l}{ Poverty gap $\left(\widehat{P G}_{p}\right)$} & & \multicolumn{2}{l}{ Squared poverty gap $\left(\widehat{P S}_{p}\right)$} \\
\cline { 2 - 3 } & 2015 & 2016 & & 2015 & 2016 & & 2015 & 2016 \\
\hline Marriages without children & 0.075 & 0.082 & & 0.251 & 0.251 & & 0.111 & 0.113 \\
Marriages with one child & 0.104 & 0.093 & & 0.255 & 0.259 & & 0.114 & 0.122 \\
Marriages with two children & 0.140 & 0.098 & & 0.254 & 0.250 & & 0.111 & 0.110 \\
Marriages with three children & 0.221 & 0.144 & & 0.236 & 0.235 & & 0.099 & 0.092 \\
Marriages with four and more & 0.389 & 0.167 & & 0.231 & 0.183 & & 0.091 & 0.063 \\
Total & 0.153 & 0.141 & & 0.248 & 0.239 & & 0.103 & 0.098 \\
\hline
\end{tabular}

Values are weighted. Source: Own calculations using data from the Household Budget Survey (Statistics Poland 2015, 2016)

exception was for marriages without children, where the decile share ratio $\left(\widehat{W}_{10 / 10}\right)$ increased and the disparity index $\left(\widehat{K}_{1 / 10}\right)$ decreased.

The level of income inequality is related to the level of material poverty, as distributions with a high level of inequality are usually more at risk of high poverty rates The results of the poverty analysis (Table 3 and Figs. 1, 2, and 3) report the estimates of poverty indices $\left(\widehat{W}_{p}, \widehat{P G}_{p}, \widehat{P S}_{p}\right)$ for different family types and the whole country.

Material poverty by family types and changes during the period were analysed using various indicators based on a poverty threshold. The relative poverty threshold (poverty line) was adopted in line with the Eurostat approach. (60\% median of equivalent national income). The poverty threshold was estimated for 2015 as PLN 1258.61. In 2016 it increased to PLN 1343.14, providing a measure of change equal to $106.7 \%$. The poverty threshold in 2016 was $6.7 \%$ higher than the respective level in 2015 .

In Figs. 1, 2 and 3 variability can be observed over different family types and over time, in the head-count ratio, the poverty gap index and the squared poverty gap index,

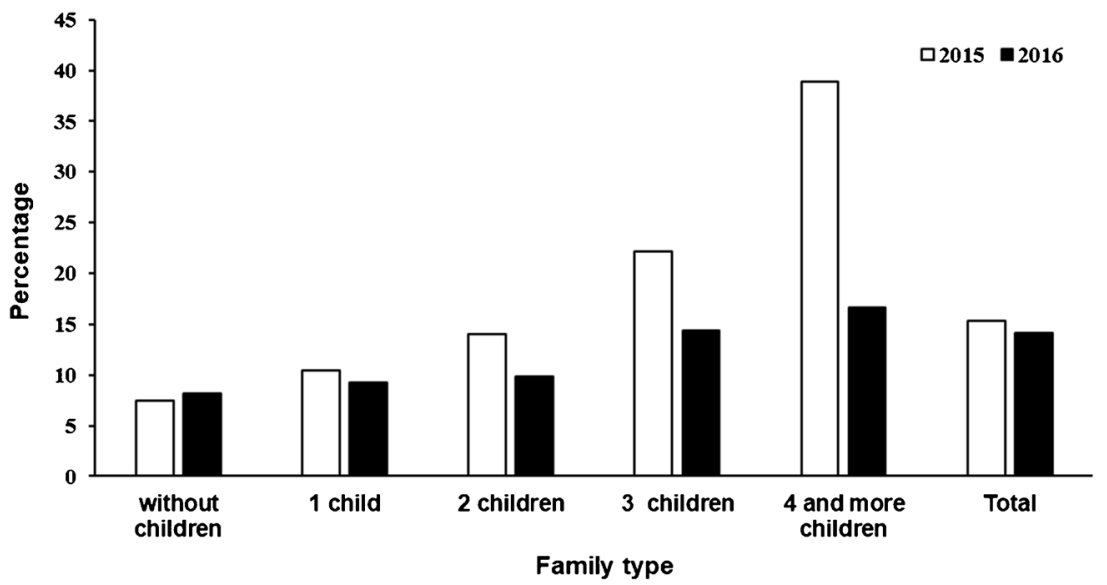

Fig. 1 Head-count ratio by family type in 2015-2016 (values are weighted). Source: Own calculation using data from the Household Budget Survey (Statistics Poland 2015, 2016) 


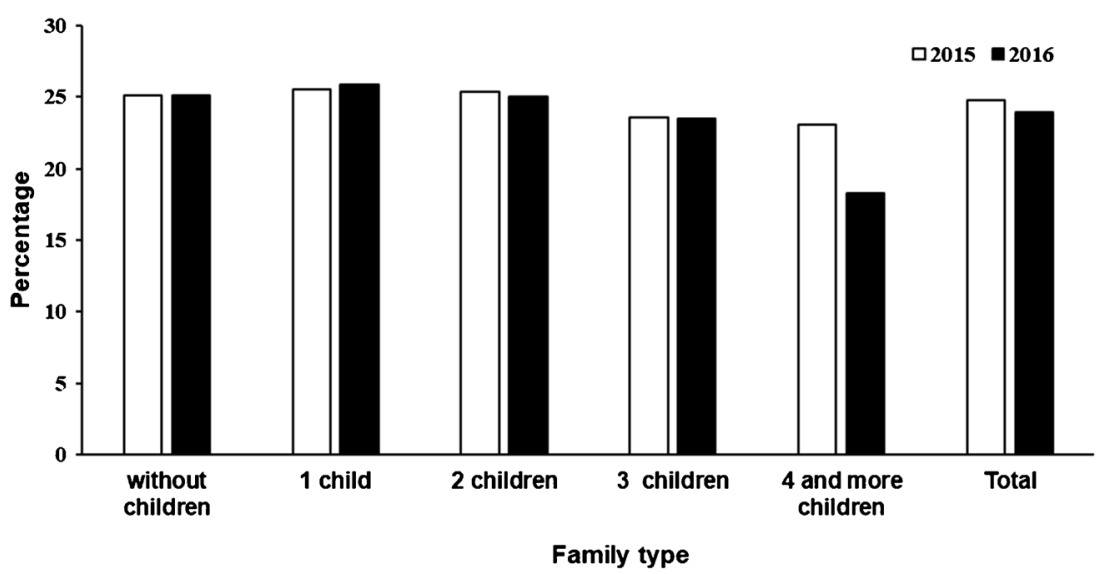

Fig. 2 Poverty gap index by family type in 2015-2016 (values are weighted). Source: Own calculation using data from the Household Budget Survey (Statistics Poland 2015, 2016)

respectively. Differences between the types of households in Poland were the highest for the head-count ratio. For the poverty gap index, the groups were more homogenous. The estimated values of the head-count ratios increased as the number of children in a family increased and reached an extremely high level for marriages with four and more children in 2015 (Fig. 1). For this group the poverty gap and squared poverty gap indices were the smallest, mainly due to low inequality among the poor households.

The significance of the differences between the means for different family types was examined using statistical hypothesis testing. The results of the two-sample $t$-tests for population means are presented in Table 4 . According to the third column of this table, the differences were statistically significant and the $p$-values for the marriages with two, three and four and more children were smaller than 0.0001 .

In 2016, a significant decline in head-count-ratios $\widehat{W}_{p}$ was also observed, especially for marriages with two children or more. Using two-sample $t$-tests to compare population proportions, the $p$ values for these family types were smaller than 0.0001

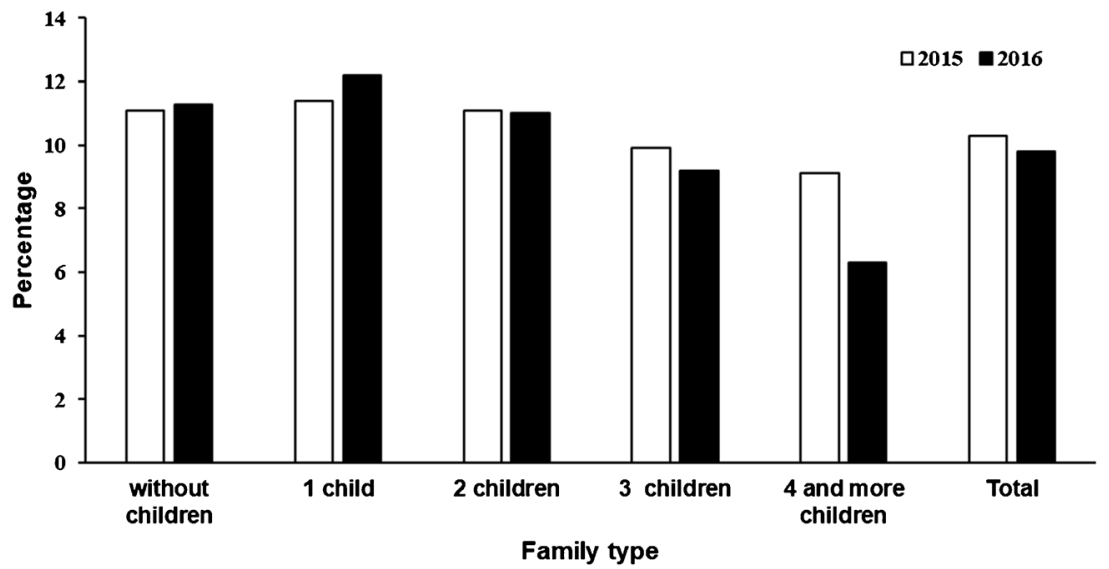

Fig. 3 Squared poverty gap index by family type in 2015-2016 (values are weighted). Source: Own calculation using data from Household Budget Survey (Statistics Poland 2015, 2016) 
Table 4 Changes in mean incomes and head-count ratios for different family types

\begin{tabular}{|c|c|c|c|c|c|c|}
\hline \multirow[t]{3}{*}{ Family type } & \multicolumn{3}{|c|}{ Mean income } & \multicolumn{3}{|c|}{ Head-count ratio } \\
\hline & \multirow{2}{*}{$\begin{array}{l}\text { Difference } \\
2016-2015\end{array}$} & \multicolumn{2}{|l|}{$t$-test } & \multirow{2}{*}{$\begin{array}{l}\text { Difference } \\
2016-2015\end{array}$} & \multicolumn{2}{|l|}{$t$-test } \\
\hline & & $t$ & $p$ value & & $t$ & $p$ value \\
\hline Marriages without children & 78.99 & 3.07 & 0.0011 & 0.007 & 1.78 & 0.0375 \\
\hline Marriages with one child & 117.74 & 2.97 & 0.0015 & -0.011 & -1.60 & 0.0504 \\
\hline Marriages with two children & 231.61 & 4.63 & 0.0000 & -0.042 & -5.58 & 0.0000 \\
\hline Marriages with three children & 380.60 & 5.62 & 0.0000 & -0.077 & -4.18 & 0.0000 \\
\hline Marriages with four and more & 599.13 & 5.27 & 0.0000 & -0.222 & -5.20 & 0.0000 \\
\hline Total & 127.32 & 10.43 & 0.0000 & -0.012 & -4.59 & 0.0000 \\
\hline
\end{tabular}

Values are weighted. Source: Own calculation using data from the Household Budget Survey (Statistics Poland 2015, 2016)

(Table 4). Thus, the percentage of poor families was significantly smaller in 2016 than in 2015.

Particularly notable differences appeared for the marriages with four or more children, where the share of poor households in the population of all households measured by the head-count ratio was $38.9 \%$ in 2015 and decreased to $16.7 \%$ (Fig. 1). For the remaining groups, marriages without children and with one child, the differences were smaller with $p$ values equal to 0.0375 and 0.0504 , respectively. Also, for marriages with four or more children, a drop in the poverty gap $\widehat{P G}_{p}$ and squared poverty gap $\widehat{P S}_{p}$ indicators was observed. Thus, the distance between the poor and non-poor families decreased. The product of the $\widehat{P G}_{p}$ index and the poverty line, interpreted as the average amount that would have to be given to poor households so that the poverty phenomenon would be totally eliminated, decreased in 2016 compared to the previous year for marriages with at least four children. In particular: $\widehat{P G}_{p} \cdot y_{p}^{*}$ $=0.183 \cdot 1343.14=245.80 \mathrm{PLN}$ in $2016 ; \widehat{P G}_{p} \cdot y_{p}^{*}=0.231 \cdot 1258.61=290.74$ PLN in 2015. In total, poverty decreased by 1.2 percentage points (Table 4 ) which means that approximately 160,000 households came out of poverty.

\section{Conclusions}

The aim of the research was to compare income inequality and poverty for different types of the Polish households. Special attention was paid to changes in the income distribution observed in the period 2015-2016, when the Family 500+ program was launched. The program had a noticeable impact on the income distribution of the Polish households, which resulted in poverty and inequality reductions, especially for lower income groups. Based on the estimated measures, it can be concluded that in 2016 significant changes $(p<0.0001)$ were observed in both average income and the degree 
of poverty for families with children. Particularly notable differences appeared in families with four or more children where the share of poor households in the population decreased from $38.9 \%$ to $16.7 \%$. In total, poverty decreased by 1.2 percentage points which means that approximately 160,000 households came out of poverty. Further improvements in the situation of families with children in Poland are expected as various EU policies have addressed numerous issues linked to child poverty in the fields of education and training, health, children's rights and gender equality. These policies go beyond ensuring children's material security, but can strengthen the observed effect of improved material situation and can help improve policy efficiency and effectiveness through innovative approaches, while taking into account differing needs at the local, regional and national levels.

Open Access This article is licensed under a Creative Commons Attribution 4.0 International License, which permits use, sharing, adaptation, distribution and reproduction in any medium or format, as long as you give appropriate credit to the original author(s) and the source, provide a link to the Creative Commons licence, and indicate if changes were made. The images or other third party material in this article are included in the article's Creative Commons licence, unless indicated otherwise in a credit line to the material. If material is not included in the article's Creative Commons licence and your intended use is not permitted by statutory regulation or exceeds the permitted use, you will need to obtain permission directly from the copyright holder. To view a copy of this licence, visit http://creativecommons.org/licenses/by/4.0/.

\section{References}

Aizer, A., Eli, S., Ferrie, J., \& Lleras-Muney, A. (2016). The long-run impact of cash transfers to poor families. American Economic Review, 106(4), 935-971.

Butcher, K. F. (2017). Assessing the long-run benefits of transfers to low-income families. Working paper \#26, Washington: Hutchins center https://www.brookings.edu/wp-content/uploads/2017/01/wp26_ butcher_transfers_final.pdf last accessed Sept. 2019.

European Commission. (2013). Investing in children: Breaking the cycle of disadvantage. Commission Recommendation of 20.2.2013. Brussels: European Commission https://eur-lex.europa.eu/eli/reco/2013 /112/oj last accessed Sept. 2019.

Eurostat. (2013). Household Composition, Poverty and Hardship Across Europe. Luxembourg: European Commission https://ec.europa.eu/eurostat/web/products-statistical-working-papers/-/KS-TC-13-008 last accessed Sept. 2019.

Eurostat. (2017). People at risk of poverty or social exclusion by age and sex https://appsso.eurostat.ec.europa. eu/nui/show.do?dataset=ilc_peps01\&lang=en last accessed Sept. 2019.

Foster, J. E., Greer, J., \& Thorbecke, E. (1984). A class of decomposable poverty measures. Econometrica, 52(3), 761-766.

Greselin, F., Pasquazzi, L., \& Zitikis, R. (2013). Contrasting the Gini and Zenga indices of economic inequality. Journal of Applied Statistics, 40(2), 282-297.

Hills, J., McKnight, A., Bucelli, I., Karagiannaki, E., Vizard, P., Yang, L., Duque, M., \& Rucci, M. (2019). Understanding the relationship between poverty and inequality: Overview report. CASE report 119. London: Centre for Analysis of Social Exclusion, LSE http://eprints.lse.ac.uk/100396/5/CASEreport1 19. pdf last accessed Sept. 2019.

Jäntti, M., \& Bradbury, B., (2001). Child poverty across industrialized countries. Journal of Population and Social Security (Population), Supplement to Volume 1, 385-410.

Jędrzejczak, A. (2012). Estimation of concentration measures and their standard errors for income distributions in Poland. International Advances in Economic Research, 18(3), 287-297.

Jędrzejczak, A., \& Kubacki, J. (2013). Estimation of income inequality and the poverty rate in Poland by region and family type. Statistics in Transition, 14(3), 259-378.

Lemmi, A., Grassi, D., Masi, A., Pannuzi, N., \& Regoli, A. (2019). Methodological choices and data quality issues for official poverty measures: Evidences from Italy. Social Indicators Research, 141(1), 299-330. 
Monti, M. G., Pelegrino, S., \& Vernizzi, A. (2015). On measuring inequity in taxation among groups of income units. Review of Income and Wealth, 61(1), 43-58.

Organisation for Economic Cooperation and Development. (2019). OECD Income Distribution Database (IDD): Methods and Concepts http://www.oecd.org/social/income-distribution-database.htm last accessed Aug. 2019.

Statistics Poland. (2015). Household budget survey (Budżety Gospodarstw Domowych) https://stat.gov. pl/obszary-tematyczne/warunki-zycia/dochody-wydatki-i-warunki-zycia-ludnosci/budzety-gospodarstwdomowych-w-2015-r-,9,10.html last accessed Feb. 2019.

Statistics Poland. (2016). Household budget survey (Budżety Gospodarstw Domowych) https://stat.gov. pl/obszary-tematyczne/warunki-zycia/dochody-wydatki-i-warunki-zycia-ludnosci/budzety-gospodarstwdomowych-w-2016-r-,9,11.html last accessed Feb. 2019.

Szarfenberg, R. (2017). Effect of child care benefit (500+) on poverty based on microsimulation. Polityka Spoteczna, 44(1/13), 25-31.

Publisher's Note Springer Nature remains neutral with regard to jurisdictional claims in published maps and institutional affiliations. 